\title{
The origin and homology of the jointed appendages of carpoid and pelmatozoan echinoderms
}

\author{
S.V. Rozhnov \\ Borissiak Paleontological institute RAS, Profsoyuznaya, 123, Moscow, 117997 Russia. E-mail: \\ Rozhnov@paleo.ru
}

ABSTRACT: The study of the origin and homology of the jointed appendages used for feeding, attachment and motion in the Pelmatozoa (Crinozoa and Blastozoa) and the Carpozoa (Soluta, Cincta, and Stylophora) is primarily based on reconstructions of the ontogeny of these animals. The presence or absence of some key processes occurring in the ontogeny of recent crinoids can be revealed in the early Paleozoic pelmatozoan and carpoid echinoderms by analyzing their adult and aberrant morphologies. Similarities in the morphology of crinoid arms, blastozoan brachioles and the feeding appendage of solutes can be explained by a similar growth pattern, based on the initial organizing role of the radial ambulacral canal. This growth model can be referred to as the model of apical serial enantiomorphic monopodial branching (ASEM-branching model). Differences between crinoid arms and blastozoan brachioles derive from the initiation of the crinoid arms anlagen in the closed vestibular sac. The solute feeding appendage is actually a pharyngeal extension. The hydrocoel was sac-like and did not grow around the pharynx in the solute ontogeny while torsion was present. The homoiostele of solutes is a homologue of the crinoid and blastozoan stem because it originated from the larval preoral lobe and right somatocoel. Cincta underwent torsion during development. The homology of cinctan marginals to those of Ctenoimbricata, Courtessolea, and the Ctenocystoidea is unlikely because these groups have very different internal body plans. Stylophorans lacked torsion and the aulacophore originated from the preoral lobe and food groove similar with the endostyle of tunicates and lanceletes. Most probably, the aulacophore was lacking of longitudinal (radial) canal.

How to cite this article: Rozhnov S.V. 2017. The origin and homology of the jointed appendages of carpoid and pelmatozoan echinoderms // Invert. Zool. Vol.14. No.2. P. 174181. doi: 10.15298/invertzool.14.2.12

KEY WORDS: Crinoidea, Blastozoa, Soluta, Cincta, Stylophora, stem, arms, brachioles, aulacophore.

\section{Происхождение и гомологии сегментированных} придатков карпоидных и пельматозойных иглокожих

\section{С.В. Рожнов}

Палеонтологический институт им. А.А. Борисяка РАН, Профсоюзная, 123, Москва, 117647 Poccuя. E-mail:Rozhnov@paleo.ru

РЕЗЮМЕ: Изучение происхождения и гомологии сегментированных придатков, используемых для питания, прикрепления и движения у Pelmatozoa (Crinozoa и Blastozoa) и Carpozoa (Soluta, Cincta, и Stylophora), основано, прежде всего, на 
реконструкции онтогенеза этих животных. Присутствие или отсутствие в онтогенезе раннепалеозойских пельматозойных и карпоидных иглокожих тех или иных ключевых процессов, известных в онтогенезе современных криноидей, может быть опознано по анализу морфологии взрослых и аберрантных форм. Сходство в морфологии рук криноидей, брахиол бластозой и пищесборных придатков солют объясняется сходной моделью роста, основанной на исходной организующей роли радиального амбулакрального канала. Такая модель роста названа моделью апикального сериального энантиоморфного моноподиального ветвления (модель АСЭМ-ветвления). Различие между руками криноидей и брахиолами бластозой возникает из-за формирования зачатка рук криноидей в замкнутой вестибулярной полости. Пищесборный придаток солют фактически представляет собой продолжение глотки. Гидроцель у них был мешкообразным и не разрастался вокруг глотки, хотя торсионный процесс у них в онтогенезе уже существовал. Гомойостела солют гомологична стеблю криноидей и бластозой, так как формировалась из личиночной преоральной лопасти при участии правого соматоцеля. Торсионный процесс в онтогенезе цинкт существовал. Гомология маргиналей цинкт с маргиналиями Ctenoimbricata, Courtessolea и Ctenocystoidea маловероятна, так как эти группы имели слишком различный внутренний план строения. Стилофоры не имели в онтогенезе торсионного процесса, их аулакофор формировался из преоральной лопасти и пищесборного желобка, сходного с эндостилем туникат и ланцетника. Продольный (радиальный) амбулакральный канал, скорей всего, отсутствовал в аулакофоре.

Как цитировать эту статью: Rozhnov S.V. 2017. The origin and homology of the jointed appendages of carpoid and pelmatozoan echinoderms // Invert. Zool. Vol.14. No.2. P. 174181. doi: 10.15298/invertzool.14.2.12

КЛЮЧЕВЫЕ СЛОВА: Crinoidea, Blastozoa, Soluta, Cincta, Stylophora, стебель, руки, брахиолы, аулакофор.

\section{Introduction}

Carpoids, or homalozoans, are a stage in the evolution of echinoderms before the appearance of pentaradial symmetry. They include the bilateral-symmetrical Ctenoimbricata and Courtessolea, the almost bilateral-symmetrical Ctenocystoidea lacking appendages and the bilateralasymmetrical Cincta, Soluta, and Stylophora, which had a tail-like/stalk-like and/or foodgathering jointed appendage, the origin and homologies of which are debated. The analysis of the morphology of these jointed appendages and a reconstruction of their morphogenesis based on comparison with similar appendages of crinoids and extinct blastozoans sheds light on the origin and early evolution of echinoderms and helps to understand the origin of their radial symmetry.

\section{Results and discussion}

\section{Key processes in crinoid ontogeny}

The ontogeny of Recent crinoids has six key successive semi-autonomous (modular) processes, the presence or absence of which in the ontogeny of echinoderms is reflected in the morphology of their adult forms: (1) a bilateralsymmetrical emergence of coeloms; (2) a bilateral-asymmetrical development of the anterior and mid-region coeloms; (3) an antero-ventral formation of the mouth (4) an attachment to the ground by the preoral lobe and a subsequent torsion event (mouth shifted to the former aboral end of the larva), leading to the inversion of the coeloms and their stacked arrangement; (6) the left middle coelom (hydrocoel) growing around the oesophagus, closing into a hollow 
ambulacral ring, and the development of an incipient pentaradial radial canal in the enclosed vestibulum (Engle, 2013; Amemiya et al., 2016). These six modular processes constitute the morphogenetic background of the appearance of jointed appendages (arms and stem), which are the primary focus of this paper. The hydrocoel symmetry organizes the symmetry of the thecal skeleton. The radial canal grows terminally, with ambulacral tentacles branching alternatively to the right and to the left, and organizes accordingly the model of apical serial enantiomorphic monopodial branching (ASEMbranching model) development of the cover plates and brachials with extending pinnules (Rozhnov, 2016). The chambered organ separated from the right posterior coelom, defines the symmetry of the stem.

The closed arch of joined oral plates present in some pedomorphic Paleozoic crinoids shows that the incipient ambulacral radial canals of the arms have been formed in the vestibular cavity (Fig. 1A). This induced the apical serial growth of the radials of the theca at the tegmen border and the development of the arm support skeleton from the brachials (Rozhnov, 2016).

\section{Blastozoa}

This subphylum includes classes of exclusively Paleozoic echinoderms with a theca of various morphology raised on a stem, and an exothecal food-gathering system with brachioles (Sprinkle, 1973). The main differences between the arms and the brachioles are as follows: (1) the position of the radial canal outside the theca of blastozoans on the entire length of ambulacra (exothecal position); (2) the biserial supporting skeleton of the brachioles is in fact a series of flooring plates; (3) the absence of gonads and extension of the sex cord in the brachioles, suggested by the presence of the gonopore in the blastozoan theca; (4) the diameter of the food groove of the brachioles is usually significantly, almost an order of magnitude, less than that of the arm of crinoids. The similarities in the arm and brachiole morphology can be explained by a similar model of
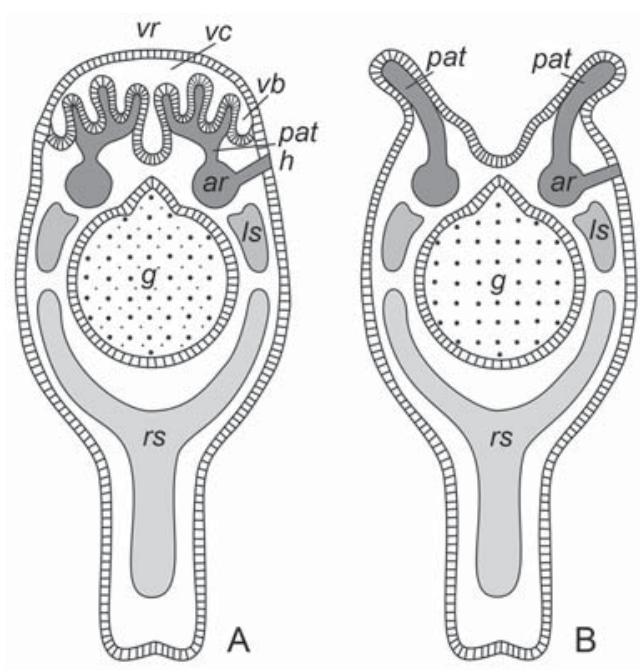

Fig. 1. Schematic drawing of the ontogenetic appearance of the endothecal arms of crinoids in the closed vestibular sac (A) and exothecal brachiole system on the surface of the developing theca of blastozoan echinoderms (B).

Abbreviations: ar - ambulacral ring, arc - ambulacral radial canal, g- gut, $\mathrm{h}$ - hydropore, ls — left somatocoel, pat - primary ambulacral tentacles (rudiment of radial ambulacral canal), rs — right somatocoel, vb — vestibular bottom, vr - vestibular cavity, vr - vestibular roof.

Рис. 1. Схема появления зачатков эндотекальных рук криноидей в замкнутой вестибульной полости (А) и экзотекальных брахиол на поверхности формирующейся теки бластозойных иглокожих (B).

Обозначения: ar - амбулакральное кольцо, arc амбулакральный радиальный канал, $\mathrm{g}$ - кишка, $\mathrm{h}-$ гидропора, ls - левый соматоцель, pat - первичные амбулакральные щупальца (зачаток радиальных амбулакральных каналов), rs - правый соматоцель, vb дно вестибулума, $\mathrm{vr}$ - вестибульная полость, $\mathrm{vr}$ свод вестибулума.

growth based on the organizing role of the radial canal, which in the terminology of developmental biology can be referred to as the embryonic inductor or organizer of the development of the associated organs of the arms (Rozhnov, 2016). Possibly, blastozoans, unlike crinoids, did not have a closed vestibular cavity, so the anlagen of the radial ambulacral canals developed immediately on the surface of the larvae, around the mouth (Fig. 1B).

In most blastozoans, possibly, the chambered organ was not developed as a structure 
separated from the right posterior coelom. However, in some taxa it could be three-chambered, judging from the tri-lobed outline of the axial canal of the stem.

\section{Soluta}

The Soluta lacked a radial symmetry (Fig. 2). Their elongated-rounded or oval triangular flattened theca has two-segmented appendages: a food-gathering (brachiole) and a tail-like (homoiostele). The brachiole is built of biserial, rarely uniserial, plates flooring the food groove

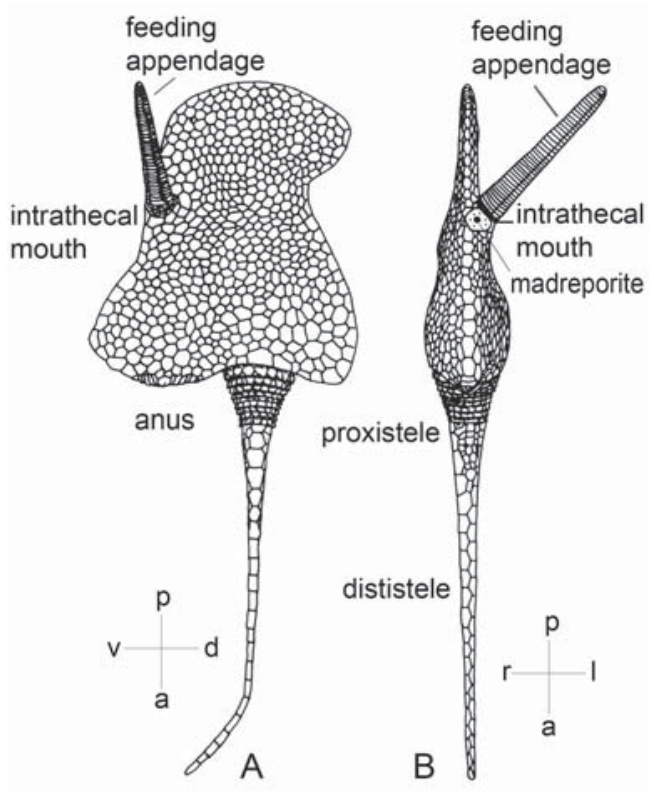

Fig. 2. Solute Maennilia estonica (Late Ordovician) and a possible relation of an adult solute to the larva's bilateral symmetry. A - upper view; B lateral view.

Possible directions of the larva axes in relation to the adult solute are lettered: a — anterior, $\mathrm{d}$ - dorsal, 1 - left, $\mathrm{p}$ posterior, $\mathrm{r}$ - right, $\mathrm{v}$ - ventral.

Рис. 2. Солюта Maennilia estonica (поздний ордовик) и возможные отношения осей взрослых солют с билатеральной симметрией личинки. А вид сверху; В - вид с левой стороны.

Возможные направления осей личинки по отношению к ориентации взрослых солют обозначены буквами: a - передний конец, d - спинная сторона, 1 - левая сторона, $\mathrm{p}$ - задний конец, $\mathrm{r}$ - правая сторона, $\mathrm{v}$ вентральная сторона. and biserial alternating covering plates. The food groove transits into the intrathecal mouth and is a continuation of the oesophagus. The hydropore/madreporite and the gonopore lie next to the brachiole. The brachiole is located either near the elongated end of the theca opposite the homoiostele, or noticeably shifted proximally along the edge of the flattened theca. The homoiostele leans to the theca by the wide proximal part of 6-8 flexible rings of small plates, rapidly narrows and becomes a long biserial distal part of the elongated paired alternating plates. The flexible proximal part contains a large cavity, connected with the thecal cavity by a wide opening. The periproct lies laterally, near the homoiostele, usually on the same side of the theca as the brachiole.

The homoiostele is thought to be homologous to the post-anal stalk of hemichordates or the stem of blastozoans. The tail homology of the homoiostele is based on its position near the anus, and the mouth being on the opposite side of the body (Rozhnov, Jefferies, 1996). The presence of the attachment structure on the end of the homoiostele in this case is explained as a facility for facultative attachment, similar to the adhesive patch on the post-anal tail of hemichordates used for temporary attachment (Smith, 2008).

The stem homology of the homoiostele is based on the presence of the disk-like terminal attachment structure (Daley, 1996), homologous to the attachment patch on the end of the blastozoan stem (Parsley, 1997). This is suggested by the secondary compression of the theca and its placement on the seafloor, reduced muscles of the homoiostele and the lateral position of the anus in relation of the homoiostele similar to its position in some rhombiferans. In many solutes, e.g., in Maennilia, the brachiole is shifted from the apical position posteriorly, toward the anus, or rarely, to the side opposite the anus (Fig. 2A, B). This shift can be explained by the retention or overdevelopment (rarely) of torsion in the ontogeny of solutes as it is known in some crinoids and blastozoans (Rozhnov, 1998, 2002, 2012). If this hypothesis is correct, the bilateral plane of the larva corre- 
sponds to the compression plane of the theca (Fig. 2B). The side with the anus in such a case would be corresponded to the ventral plane of the larva, while the opposite side - to the dorsal plane (Fig. 2A). Maennilia was lying right-side up, and the anus was to the left of the homoiostele (Rozhnov, Jefferies, 1996). Many other solutes apparently lay on the seafloor left side up (Noailles et al., 2014). Hence, after the attached larval stage, different solutes could lie on opposite sides of the theca. The reliability of the torsion presence in solutes can be supported by further discoveries of attached juvenile or adult solutes showing that the attachment of the Cambrian solutes was not a rare, unusual specialization of their tail, but a fundamental feature of the stem morphogenesis (Daley, 1996).

\section{Cincta}

Cinctans have a compressed-rounded or rounded-triangular theca with a mouth and anus in the anterior region and segmented appendage (stele) in the posterior region (Fig. 3). The theca is built of marginal plates, framing the central field on the upper (dorsal) and lower (ventral) side of the body, filled by small tessellated plates. An operculum covering the atrial cavity is positioned between the mouth and the anus. One or two food grooves extends from the mouth dorsally over the flattened peripheral region of the marginal plates. The food grooves are covered by alternating biserial or in a different way arranged cover plates (Smith, Zamora, 2009). The presence of the only one food groove is a plesiomorphic character, and the presence of two grooves is an apomorphic one. A number of food grooves is not indicative for the presence or an absence of the right middle coelom as considered by Rahman and Zamora (2009), and reflects the beginning of the left middle coelom serial overgrowth around pharynx. The position of the anus on the same side of the theca as the mouth, opposite the stele, suggests a torsion (a dislocation of the mouth rudiment from the ventral anterior place to the upper posterior one) in the ontogeny of cinctas. Consequently, the stele is a derivative of the pre-oral lobe of the

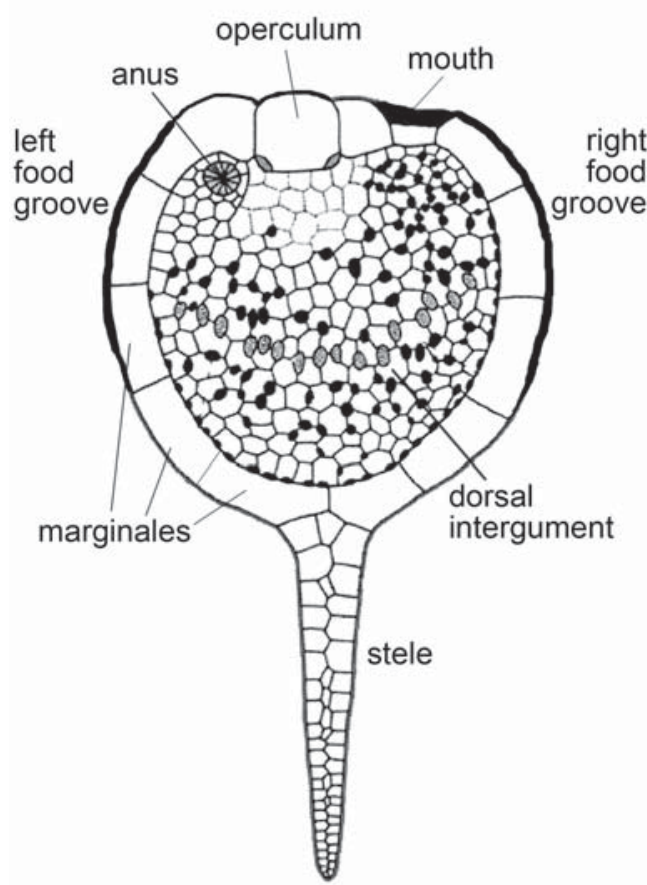

Fig. 3. General upper view of a cinctan (Trochocystites).

Рис. 3. Общий вид сверху цинкты Trochocystites.

larva and of the posterior right somatocoel. Thus, it could be homologous to the stem of crinoids and blastozoans. This hypothesis can be supported by future discoveries of solutes with an attachment structure on the end of the stele, at least in juveniles. But in any case, cinctas as well as solutans are not blastozoan because they primarily did not have the pentameral symmetry.

The homologization of marginal plates contouring the theca of cinctans with the marginals of the Ctenocystoidea, Ctenoimbricata, and Courtessolea (Zamora et al., 2012), which did not have segmented appendages, seems very unlikely. The thecal plates hardly could retain their arrangement in the existing body plan after a torsion, which these echinoderms certainly did not undergo. More so, it is suggested that these groups were bilaterally symmetrical ancestors of other echinoderms. If this was the case, they should have had right and left co- 


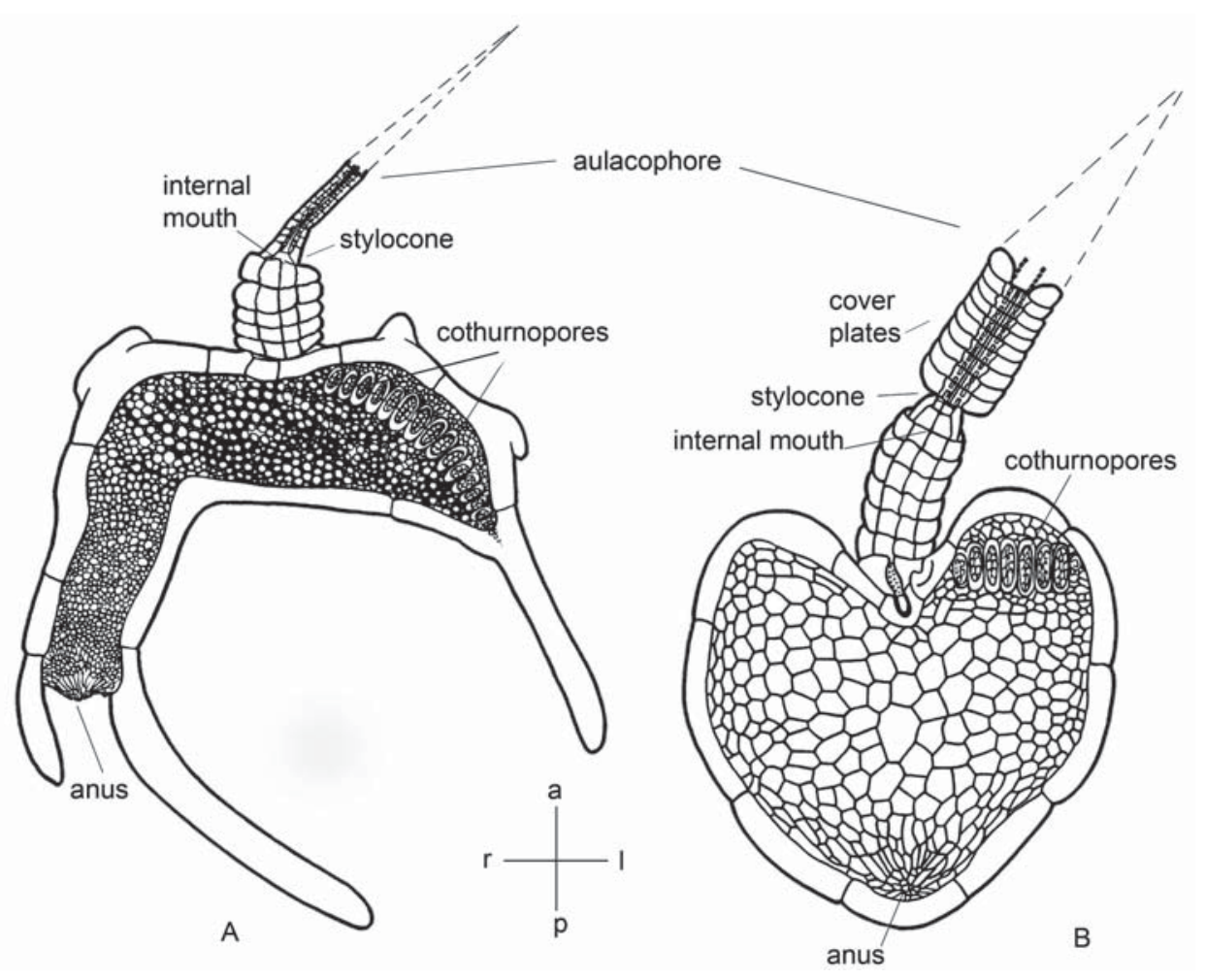

Fig. 4. Stylophorans: general upper view of two species. A - strongly bilaterally-asymmetrical immobile Cothurnocystis; B - more bilaterally-symmetrical Phyllocystis capable of moving with a horizontally wagging aulacophore. Upper surface of the adult stylophorans corresponds to the ventral surface of their larva; lower surface corresponds to the dorsal one. Other axes are lettered as in Fig. 2.

Рис. 4. Стилофоры: общий вид сверху двух видов. А - резко билатерально-асимметричный неподвижный Cothurnocystis; В - почти билатерально-симметричный Phyllocystis, способный двигаться при горизонтальном вилянии хвостом. Верхняя поверхность взрослых стилофор соответствует вентральной поверхности их личинки, а нижняя - дорзальной. Направление остальных осей показано буквами. Обозначения как на рис. 2.

eloms equally well developed, so the transition to a bilateral-asymmetric body plan and a significant change in the deep ontogeny could not have left the thecal plate arrangement unchanged.

\section{Stylophora}

Stylophorans had an asymmetric theca with an appendage (Fig. 4A, B), which is interpreted as a tail (Jefferies, 1996) or a specialized process, aulacophore (Ubaghs, 1967; Parsley, 1997). The functional morphological analysis shows that this process served for food gather- ing and to a lesser extent for motion, i.e., was an aulacophore (Rozhnov, Parsley, 2017). Consequently, the mouth was located in its proximal region, where the ambulacral groove is located on the stylocone (Fig. 4A, B). As stylophoran ontogeny does not show traces of torsion, it can be suggested that the aulacophore is a derivative of the pre-oral lobe of the larva as a result of its serial terminal growth, with the anterior coelom growing into it as in larvae of some starfish. If this supposition is right the upper surface with a mouth and cothurnopores of adult stylophorans corresponds to the ventral surface of their larva 
with ventrally-anterior mouth. The groove with the ciliate epithelium also extended from the pharynx. The arrangement of flooring plates as well as cover plates usually correspond to the pattern of the tube feet branching in recent echinoderms. If this correspondence was true for stylophorans, the paired tentacular branching pattern of the longitudinal ambulacral canal in the aulacophore is very different from that of recent echinoderms and most likely suggests that the aulacophore did not have an ambulacrum (Rozhnov, Parsley, 2017).

In the absence of a radial canal, organic particles were brought from the seafloor by current turbulences or by aulacophore distortion of the sediment and directed by the ciliate epithelium to the mouth. After that, food particles were transferred to the gut while filtered water was expelled through the cothurnopores, which in this case functioned as gill slits. The latter interpretation agrees with Jefferies (1986), but he reaches the opposite conclusion on the anterior and posterior ends of the body and the position of the mouth and anus of the animal.

\section{Conclusions}

The analysis of the segmented appendages of pelmatozoans and carpoids (excluding stilophorans) shows that the stem and the external food system in these groups appeared before the pentaradial symmetry, and their appearance was connected to torsion during ontogeny. Stylophorans had an appendage (aulacophore), partly homologous to the stem of the pelmatozoans because it appeared as a result of the serial growth of the pre-oral lobe of the larva. It principally differs from the stem by possible presence of the anterior coelom and by the food groove, apparently lacking the radial canal like endostyle of tunicates and lancelets. The first brachiole-like appendage known in solutes appeared before the formation of the pentaradial symmetry. Its similarity to brachioles of blastozoans and arms of crinoids is explained by a similar growth pattern of the skeleton, based on the primary organizing role of the longitudinal ambulacral canal initial for the radial canals of the pentameric echinoderms. Differences between blastozoan brachioles and crinoid arms derived from the initiation of the crinoid arms anlagen in the closed vestibular cavity, while the brachiolar food-gavering system developed on a larva at once.

\section{Acknowledgements}

The study is supported by the Russian Foundation for Basic Research, project 15-04-08315a, by the program of Presidium RAS No. 21 and it is a contribution to IGCP project 653 .

\section{References}

Amemiya S., Omori A., Tsurugaya T., Hibino T., Yamaguchi M., Kuraishi R., Kiyomoto M., Monokawa T. 2016. Early stalked stages in ontogeny of the living isocrinid sea lily Metacrinus rotundus // Acta Zoologica (Stockholm). Vol.97. P.102-116.

Daley P.E.J. 1996. The first solute which is attached as an adult: a Mid-Cambrian fossil from Utah with echinoderm and chordate affinities // Zoological Journal of the Linnean Society. Vol.117. P.405-440. DOI: 10.1111/j.1096-3642.1996.tb01659.x

Engle S. 2013. Ultrastructure and development of the body cavities in Antedon bifida (Pennant, 1777) (Comatulida, Crinoidea). Unpublished $\mathrm{PhD}$ thesis. See http:// edocs.fu-berlin.de/diss/receive/ FUDISS_thesis 000000040355

Jefferies R.P.S. 1986. The Ancestry of the Vertebrates. London: British Museum (Natural History). 376 p.

Noailles F., Lefebvre B., Kašička L. 2014. A probable case of heterochrony in the solutan Dendrocystites Barrande, 1887 (Echinodermata: Blastozoa) from the Upper Ordovician of the Prague Basin (Czech Republic) and a revision of the family Dendrocystitidae Bassler, 1938 // Bulletin of Geoscience. Vol.89. No.3. P.451-476.

Parsley R.L. 1997. The echinoderm classes Stylophora and Homoiostelea: non Calcichordata // Paleontological Society Papers. No.3. P.225-248.

Rahman I.A., Zamora S. 2009. The oldest cinctan carpoid (stem-group Echinodermata), and the evolution of the water vascular system // Zoological Journal of the Linnean Society. Vol.157. P.420-432.

Rozhnov S.V. 1998. Crookedness of the stem and crown of pelmatozoan echinoderms as resulting from different kinds of heterochrony // M.D.C. Carnevali, F. Bonasoro (eds.). Echinoderm Research. Rotterdam: Balkema. P.385-390.

Rozhnov S.V. 2002. Morphogenesis and evolution of crinoids and other pelmatozoan echinoderms in the Early Paleozoic // Paleontological Journal. Vol.3. Suppl. No.6. P.S525-S674.

Rozhnov S.V. 2012. The anteroposterior axis in echinoderms and displacement of the mouth in their phylog- 
eny and ontogeny // Biology Bulletin. Vol.39. No.2. P.162-171. DOI: $10.1134 / \mathrm{S} 1062359012020094$

Rozhnov S.V. 2016. Arms versus brachioles: Morphogenetic basis of similarity and differences in foodgathering appendages of pelmatozoan echinoderms // Paleontological Journal. Vol.50. No.14. P.1598-1609. DOI: $10.1134 / \mathrm{S} 0031030116140069$

Rozhnov S.V., Jefferies R.P.S. 1996. A new stem-chordate solute from the Middle Ordovician of Estonia // Geobios. Vol.29. No.1. P.91-109.

Rozhnov S.V., Parsley R.L. 2017 (in press). A new cornute (Homalozoa: Echinodermata) from the uppermost middle Cambrian (Stage 3, Furongian) from northern Iran: Its systematics and functional morphology // Paleontological Journal. Vol.51. No.5.

Smith A.B. 2008. Deuterostomes in a twist: the origins of a radical new body plan // Evolution and Development. Vol.10. No.4. P.493-503.
Smith A.B., Zamora S. 2009. Rooting phylogenies of problematic fossil taxa; a case study using cinctans (stem-group echinoderms) // Palaeontology. Vol.52. P.803-821.

Sprinkle, J. 1973. Morphology and Evolution of Blastozoan Echinoderms. Harvard University Museum of Comparative Zoology, Special Publication. 283 p.

Ubaghs G. 1967. Stylophora// Treatise on Invertebrate Paleontology. P. S. Echinodermata 1(2). Geological Soc. Am. and Univ. Kansas Press, Boulder \& Lawrence. P.S495-S565.

Zamora S., Rahman I.A., Smith A.B. 2012. Plated Cambrian bilaterians reveal the earliest stages of echinoderm evolution // PLOS ONE. Vol.7. No.6: e38296. DOI:10.1371/journal.pone.0038296

Responsible editor E.N. Temereva 